\title{
Some College Completion
}

National Cancer Institute

\section{Source}

National Cancer Institute. Some College Completion. NCI Thesaurus. Code C67137.

Indicates that a person has attended college but that they did not receive any degree. 